Preprint

UCRL-JRNL-202412

\title{
Direct Conversion of Carbon Fuels in a Molten Carbonate Fuel Cell
}

N.J. Cherepy, R. Krueger, K.J. Fiet, A.F. Jankowski, J.F. Cooper

This article was submitted to the Journal of the Electrochemical Society

Lawrence

February 25, 2004

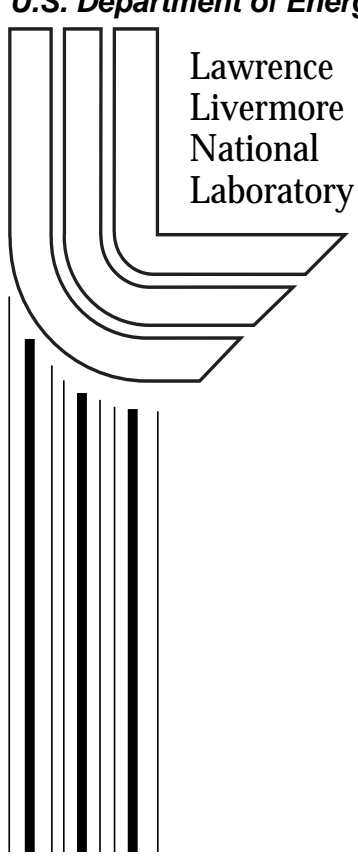




\section{DISCLAIMER}

This document was prepared as an account of work sponsored by an agency of the United States Government. Neither the United States Government nor the University of California nor any of their employees, makes any warranty, express or implied, or assumes any legal liability or responsibility for the accuracy, completeness, or usefulness of any information, apparatus, product, or process disclosed, or represents that its use would not infringe privately owned rights. Reference herein to any specific commercial product, process, or service by trade name, trademark, manufacturer, or otherwise, does not necessarily constitute or imply its endorsement, recommendation, or favoring by the United States Government or the University of California. The views and opinions of authors expressed herein do not necessarily state or reflect those of the United States Government or the University of California, and shall not be used for advertising or product endorsement purposes.

This is a preprint of a paper intended for publication in a journal or proceedings. Since changes may be made before publication, this preprint is made available with the understanding that it will not be cited or reproduced without the permission of the author. 


\title{
DIRECT CONVERSION OF CARBON FUELS IN A MOLTEN CARBONATE FUEL CELL
}

\author{
by \\ Nerine J. Cherepy*,z, Roger Krueger, Kyle J. Fiet, Alan F. Jankowski*, John F. Cooper* \\ Lawrence Livermore National Laboratory \\ Livermore CA 94550
}

*Electrochemical Society active member

z cherepy1@1lnl.gov 


\begin{abstract}
Anodes of elemental carbon may be discharged in a galvanic cell using a molten carbonate electrolyte, a nickel-foam anode-current collector, and a porous nickel air cathode to achieve power densities of 40-100 $\mathrm{mW} / \mathrm{cm}^{2}$. We report cell and anode polarization, surface area, primary particle size and a crystallization index for nine particulate carbon samples derived from fuel oil, methane, coal, charred biological material and petroleum coke. At $800{ }^{\circ} \mathrm{C}$, current densities of $50-125 \mathrm{~mA} / \mathrm{cm}^{2}$ were measured at a representative cell voltage of $0.8 \mathrm{~V}$. Power densities for cells with two carbon-anode materials were found to be nearly the same on scales of 2.8- and $60 \mathrm{~cm}^{2}$ active area. Constant current operation of a small cell was accompanied by constant voltage during multiple tests of 10-30 hour duration. Cell voltage fell off after the carbon inventory was consumed. Three different cathode structures are compared, indicating that an LLNL fabricated porous nickel electrode with $<10 \mu \mathrm{m}$ pores provides improved rates compared with nickel foam with 100-300 $\mu \mathrm{m}$ pores. Petroleum coke containing substantial sulfur and ash discharges at a slightly lower rate than purified petroleum coke. The sulfur leads to degradation of the anode current collector over time. A conceptual model for electrochemical reactivity of carbon is presented which indicates the importance of (1) bulk lattice disorder, which continually provides surface reactive sites during anodic dissolution and (2) electrical conductivity, which lowers the ohmic component of anode polarization.
\end{abstract}


Fossil fuels including coal, oil and natural gas make up $80 \%$ or more of the U.S. energy supply. It is projected they will continue to supply this fraction for the next 20 years. ${ }^{1}$ Improving efficiency in conversion and utilization of fuel will be of prime importance in reducing costs and pollution, and in extending resources. One concept for improved conversion efficiency is a direct carbon conversion fuel cell that reacts carbon particulates derived from natural gas, petroleum or its refining by-products, biomass and devolatilized coal, using electrolytes and cathodes similar to those used in the molten carbonate fuel cell. The prospects of high efficiencies are grounded in favorable thermodynamics of the carbon/oxygen reaction, $\mathrm{C}+\mathrm{O}_{2} \rightarrow \mathrm{CO}_{2}$. This cell reaction has the advantage of having a nearly zero entropy change $(\Delta \mathrm{S}=0.7 \mathrm{cal} / \mathrm{K}-\mathrm{mol})$. In contrast with the hydrogen/oxygen fuel cell, the theoretical electrochemical conversion efficiency is nearly $100 \%$, with essentially no entropic heat evolution. ${ }^{2}$ The activities of the carbon and carbon dioxide product are invariant leading to a stable anode potential that is independent of position or extent of fuel conversion. In principle, this allows full conversion of the fuel in a single pass, in a well-designed cell with sufficient airflow.

Attempts to convert coal directly to electricity in an electrochemical fuel cell date to the $19^{\text {th }}$ Century, and early literature was reviewed by Liebhafsky and Cairns. ${ }^{3}$ In his investigation of the graphite anode, Hauser ${ }^{4}$ measured an open circuit voltage at $800{ }^{\circ} \mathrm{C}$ of $0.82 \mathrm{~V}, 1 \mathrm{~mA} / \mathrm{cm}^{2}$ at $0.7 \mathrm{~V}$ (vs. reference electrode), and $45 \mathrm{~mA} / \mathrm{cm}^{2}$ at $0.3 \mathrm{~V}$. At $940{ }^{\circ} \mathrm{C}$, he measured an open circuit voltage of $1.01 \mathrm{~V}, 1 \mathrm{~mA} / \mathrm{cm}^{2}$ at $0.96 \mathrm{~V}$, and $44 \mathrm{~mA} / \mathrm{cm}^{2}$ at $0.6 \mathrm{~V}$. Also, Hauser reported that the percentage of $\mathrm{CO}$ in the effluent gas stream was $<1 \%$ at $700{ }^{\circ} \mathrm{C}, 1-2 \%$ at $800{ }^{\circ} \mathrm{C}$, and $10 \%$ at $870{ }^{\circ} \mathrm{C}$. Dubois studied carbon in molten carbonate at $560{ }^{\circ} \mathrm{C}$, and explored the dependence of the open circuit voltage on $\mathrm{O}^{2-}$ concentration for carbons of different morphologies. ${ }^{5}$ Dubois also reported the production of a poorly crystallized carbon through reduction of $\mathrm{CO}_{2}$ under an applied voltage, this carbon being much easier to electrochemically oxidize than other carbons, exhibiting an open circuit potential (vs. Au/ $\mathrm{O}_{2}, 2 \mathrm{CO}_{2}$ reference electrode) of $1.8 \mathrm{~V}$ at $\mathrm{p}\left[\mathrm{O}^{2-}\right]=6$, compared to $\sim 0.6 \mathrm{~V}$ for pyrolytic graphite, $\sim 0.7 \mathrm{~V}$ for electro-graphite and vitreous carbon and $1.0 \mathrm{~V}$ for wood charcoal.

Weaver and co-workers at Stanford Research Institute tested a range of carbons fabricated into solid anodes, including pyrolytic graphite, spectroscopic carbon and porous devolatized coals, using a spectroscopic carbon cathode in a molten carbonate system. ${ }^{6}$ Open circuit voltages ranged between 1.1 and $0.8 \mathrm{~V}$ (vs. $\mathrm{Au} / \mathrm{O}_{2}, 2 \mathrm{CO}_{2}$ ). The reactivity and open circuit voltages of these materials were found to decrease in the order, devolatilized coal $>$ spectroscopic carbon $>$ pyrolytic graphite. They correlated high reactivity with large surface area, as well as poor crystallization. The most reactive material, JPL coal, produced $100 \mathrm{~mA} / \mathrm{cm}^{2}$ at 0.8 $\mathrm{V}$ (vs. reference electrode) at $700{ }^{\circ} \mathrm{C}$, the potential at $100 \mathrm{~mA} / \mathrm{cm}^{2}$ increasing to $0.9 \mathrm{~V}$ at $800{ }^{\circ} \mathrm{C}$. Also, they 
measured the anode off-gas as $>90 \% \mathrm{CO}_{2}$ at high current density, the $\mathrm{CO}_{2} / \mathrm{CO}$ ratio decreasing at lower current densities.

Vutetakis experimented with various carbon and coal samples in the form of particulates dispersed in molten alkali carbonate electrolyte. ${ }^{7}$ These were mostly high ash content particulate materials, all in the 100 $500 \mu \mathrm{m}$ particle size range. His cell consisted of a large alumina crucible containing an alumina stirrer, a gold working electrode in physical contact with the particulate slurry, a graphite counter electrode sheathed in a closed-bottom alumina tube with a $1.5 \mathrm{~mm}$ hole allowing electrolyte contact, and a $\mathrm{Au} / \mathrm{O}_{2}, 2 \mathrm{CO}_{2}$ reference electrode. He measured the highest discharge rate for bituminous char (Kentucky no. 9) of $30 \mathrm{~mA} / \mathrm{cm}^{2}$ at $0.8 \mathrm{~V}$ (vs. reference electrode). Gur and Huggins reported an oxygen gradient cell based on a yttria-stabilized zirconia solid electrolyte, platinum electrodes, and a carbon pellet fuel that served to maintain a low partial pressure of oxygen by direct reaction with the atmosphere in the anodic side. ${ }^{8}$ The solid electrolyte was held at $800{ }^{\circ} \mathrm{C}$, while the carbon temperature was varied. At $725^{\circ} \mathrm{C}$, the open circuit voltage was $0.9 \mathrm{~V}$ and the system supported $5 \mathrm{~mA} / \mathrm{cm}^{2}$ at $0.2 \mathrm{~V}$, while at $955^{\circ} \mathrm{C}$ the open circuit voltage was $1.1 \mathrm{~V}$ and the system supported $2-3$ $\mathrm{mA} / \mathrm{cm}^{2}$ at $0.8 \mathrm{~V}$ and $20 \mathrm{~mA} / \mathrm{cm}^{2}$ at $0.2 \mathrm{~V}$. The drawback of a gradient cell, in which bulk carbon merely establishing the oxygen partial pressure, is that the atmosphere in the vicinity of the anode is subject to the Boudouard equilibrium resulting in preferential formation of $\mathrm{CO}$ rather than $\mathrm{CO}_{2}$.

The main barriers encountered by these attempts to develop a practical carbon/air fuel cell historically have been: (1) buildup of ash in the molten carbonate electrolyte, (2) low anode reaction rates, and (3) the high cost of carbon electrode manufacture and the logistics of distribution to the cells. Early researchers incorrectly assumed that the anodic reaction of carbon would be controlled by the equilibrium of the Boudouard reaction,

$$
\mathrm{C}+\mathrm{CO}_{2} \rightarrow 2 \mathrm{CO}
$$

Although this equilibrium is expected at operating temperatures above $700{ }^{\circ} \mathrm{C}$, it has been shown by several workers that carbon in molten carbonate oxidizes electrochemically in the $700-900{ }^{\circ} \mathrm{C}$ range to $\mathrm{CO}_{2}$, yielding 4 electrons per carbon atom. ${ }^{3,7}$ Also, this is the case for carbon Hall electrodes used in electrochemical aluminum refining. ${ }^{9,10}$ However, if the carbon in the anode compartment is not polarized, for example during standby or at points on the anode remote from current flow, then Eq. 1 will proceed and result in Boudouard corrosion of the fuel.

The current approach at LLNL to overcome the historical failures is to employ a low ash, high surface area elemental carbon fuel dispersed as fine particulates in a molten salt. ${ }^{11}$ Carbon particulate fuel, once wetted with molten salt, in a drained semisolid block, is thought to act like a rigid anode when in contact with an inert 
metal current collector/anode. The anode reaction takes place between the carbon and the carbonate ion from the electrolyte, releasing $\mathrm{CO}_{2}$ and electrons. At the cathode, oxygen (from air), $\mathrm{CO}_{2}$ and electrons returning from the anode produce the carbonate ion. A porous ceramic separator allows the carbonate ion to migrate between the two electrode compartments.
Anodic half reaction:
$\mathrm{C}+2 \mathrm{CO}_{3}{ }^{2-} \rightarrow 3 \mathrm{CO}_{2}+4 \mathrm{e}^{-}$
Cathode half reaction:
$\mathrm{O}_{2}+2 \mathrm{CO}_{2}+4 \mathrm{e}^{-} \rightarrow 2 \mathrm{CO}_{3}^{2-}$
Overall cell reaction:
$\mathrm{C}+\mathrm{O}_{2} \rightarrow \mathrm{CO}_{2}$

The cell voltage is given by:

$$
\mathrm{E}_{\mathrm{cel1}}=\mathrm{E}^{\circ}-(\mathrm{RT} / 4 \mathrm{~F}) \cdot \ln \left[\mathrm{CO}_{2}\right]^{3}+(\mathrm{RT} / 4 \mathrm{~F}) \cdot \ln \left(\left[\mathrm{O}_{2}\right]\left[\mathrm{CO}_{2}\right]^{2}\right)
$$

The standard potential for Eq. 4 is $1.02 \mathrm{~V}$, however, experimental open circuit voltages can be higher due to properties of the carbons, and gas concentrations, in particular, low $\mathrm{CO}_{2}$ concentrations in the anode compartment under inert gas purge will affect the second term in Eq. 5, resulting in an increased open circuit voltage, as discussed previously.

In this work, nine carbon samples were characterized for surface area (from BET analysis), primary particle size (from electron microscopy), relative graphitization (from x-ray diffraction measurements/analysis) and electrochemical reactivity in a standard cell. The samples studied were all particulate and included purified biomass char, purified coal, carbon blacks, petroleum coke, and graphites. A physical model relating carbon structure to electrochemical reactivity has been constructed from these experimental measurements.

In addition to exploring the relationship between structure and electrochemical discharge rate of various carbon materials, we have carried out studies relevant to the applicability of direct conversion carbon fuel cells. These include: (1) demonstration of a carbon/air cell on the 3 Watt scale, (2) discharge for up to 30 hours at constant current, (3) exploration of improved cathode designs, and (4) use of high-sulfur-content carbon fuels.

\section{Experimental}

Analytical characterization of carbons. The BET surface area measurements of all samples were provided by the suppliers. Sample 1, the Peach Pit acid-washed activated carbon was obtained from Scientific Carbons, Marietta, GA. Sample 2, Coconut acid-washed activated carbon (HR5-AW) and Sample 3, Coal- 
derived activated carbon (207-AW), were supplied by Waterlink, Colombus, OH. Sample 4, Acetylene Black, was supplied by ChevronPhillips Chemical Company, Houston, TX in the 100\% compressed preparation. Engineered Carbons, Borger, TX, supplied Sample 5, Arosperse 3, a furnace oil carbon black, and Sample 7, Arosperse 15, a thermal black made from methane. Sample 6, the carbon aerogel microspheres, was prepared at LLNL from a resorcinol precursor, following a previously described procedure having a resorcinol/catalyst ratio of 200, and pyrolyzed under $\mathrm{CO}_{2}{ }^{12,13}$ The aerogel microspheres are porous and high surface area. Sample 8 was a needle petroleum coke calcined at $1400^{\circ} \mathrm{C}$ (Superior Graphite, Chicago, IL) containing $<1 \%$ sulfur and about $0.15 \%$ ash. Sample 9, Desulco 9039 is a particulate graphite also obtained from Superior Graphite. Samples 1, 4, 5, 6, 7, and 9 were used as-received, while Samples 2, 3 and 8 were ball-milled to reduce the macroscopic aggregate/pellet size. This milling procedure may have increased the surface area for these materials, but additional BET measurements were not performed. A sample of petroleum coke more typical of low-grade coke produced in high volume by refineries was obtained from Conoco, Ponca City, OK. This sample was calcined at $1100{ }^{\circ} \mathrm{C}$, and contained $2.86 \mathrm{wt} \%$ sulfur, $0.5 \mathrm{wt} \%$ volatiles and $0.28 \mathrm{wt} \%$ ash.

We imaged samples using scanning electron microscopy in order to estimate primary particle size for each sample. A Hitachi S-4500, cold field emission scanning electron microscope operating at $1.6 \mathrm{KV}$ accelerating voltage was used to produce secondary electron (SE) images of the carbon samples. Digital images were captured with a Quartz PCI / PC fraame grabber and post processed in Adobe Photoshop. X-ray diffraction measurements employed a Rigaku powder diffractometer on a rotating anode utilizing copper $\mathrm{K}_{\alpha}$ radiation $\left(\lambda=0.1542 \mathrm{~nm}\right.$, linewidth in the vicinity of the $\mathrm{d}(002)$ line at $\sim 24^{\circ}$ is $0.16^{\circ}$ in $2 \Theta$, and is $0.25^{\circ}$ in the vicinity of the $80^{\circ}, \mathrm{d}(110)$ line). The most prominent line for the carbon samples studied is the $\mathrm{d}(002)$ line, at $0.3354 \mathrm{~nm}$ for graphite. All electron microscopy and x-ray diffraction characterization used samples prepared identically to those measured in the electrochemical cell.

Electrochemical measurements. Our electrochemical cell (Figure 1) contains a paste of particulate carbon fuel in a molten carbonate electrolyte $(32 \% \mathrm{Li}-68 \% \mathrm{~K}$ eutectic) in the anode compartment at a ratio of carbon to carbonate of 1:2 or less. Electrolyte is distributed among separator, cathode and anode paste by capillarity and excess is allowed do drain into the containment crucible. Cells are typically made from alumina cylinders, with nickel foam and stainless steel screen composite electrodes lending structural stability to the electrode/separator sandwich. The standard cell has electrode area of $2.8 \mathrm{~cm}^{2}$. Measurements on the larger scale $\left(60 \mathrm{~cm}^{2}\right.$ electrodes $)$ used a similar cathode/separator/anode assembly, although this assembly was held at a $45^{\circ}$ angle from the horizontal with intent of enhancing electrolyte drainage by gravity flow. Some small cells were oriented such that the cell assembly was tilted at an angle up to $45^{\circ}$ from horizontal. A mixture of carbon 
dioxide and air (to provide oxygen) flows through the cathode compartment at a ratio of 5 air: $2 \mathrm{CO}_{2}$ and a rate 1-10 times the stoichiometric requirement of equation [4]. A slow flow of argon gas is used at he anode to prevent air from entering the compartment. Alternatively a sealed cell with provisions for $\mathrm{CO}_{2}$ product gas outflow may be used. An $\mathrm{Au} / \mathrm{O}_{2}, 2 \mathrm{CO}_{2}$ reference electrode ${ }^{14}$ was used during some measurements. It was constructed from an alumina tube containing a gold wire, in contact with the bulk electrolyte composition and an overflow mixture reference gas of 5 parts air and 2 parts $\mathrm{CO}_{2}$ (by volume). The reference electrode contacted the bulk electrolyte through a 10-100 $\mu \mathrm{m}$ hole at the bottom of the tube. The reference electrode was positioned in the anode compartment, adjacent to the anode current collector for reference vs. anode measurements, and in the cathode compartment for reference vs. cathode measurements. The cell is placed inside an alumina crucible, which is held inside a ceramic heater at $700-850{ }^{\circ} \mathrm{C}$. A $0.76 \mathrm{~mm}$ thick porous zirconia cloth separator (Zircar, Florida, NY) wetted with molten carbonate lies between the anode and cathode. Most measurements used 200-300 ppi nickel foam (Retec Porous Metals, Chardon, OH) for both electrodes. Also, we tested proprietary nickel cathodes (supplied by a fuel cell company). We have prepared our own advanced nickel electrode structure, as well, having a multilayer porous structure, including submicron pores as well as pores up to $200 \mu \mathrm{m}$. The anode current collector was typically still metallic and intact at the termination of experiments, with the exception of experiments in which the cell ran out of fuel, or used high sulfur carbon.

\section{Results and Discussion}

The chemical reactivity of carbons to oxidation is known to be strongly dependent on structure, in particular, extent of graphitization and surface area. ${ }^{15}$ Nine particulate carbon samples were characterized in this work to determine how their structure might control electrochemical reactivity. Additional experiments were carried out to demonstrate the scalability of our fuel cell design as well as extended discharge of carbon fuels in molten carbonate. Also, we report tests of specially engineered molten carbonate cell cathodes for optimization of cell power. Finally, data acquired using high-sulfur petroleum coke is presented.

Electrochemical reactiviy of nine carbon samples. Electrochemical reactivity was evaluated at $800^{\circ} \mathrm{C}$ in a standardized carbon/air molten carbonate cell. The data is summarized in Table 1. Polarization curves (Figure 2), as well as measurements of discharge at constant current were acquired. In general, transient polarization curves corresponded to sustainable current voltage performance, however, at voltages below 0.6 $\mathrm{V}$ constant power conditions were typically not sustainable. All of the electrochemical data reported in Table 1 
and in Figure 2 were acquired using Retec nickel foam cathodes. Data reported are typical data for each carbon sample, not averages. However, multiple datasets for most of the carbons were obtained. In particular, the slopes of the IV curves for a specific carbon were found to be reproducible.

The highest discharge rates, $100-125 \mathrm{~mA} / \mathrm{cm}^{2}$ at $0.8 \mathrm{~V}$, were obtained with biochar-derived carbons, materials with low crystallinity, as defined by the results of the x-ray diffraction measurements (described below). Petroleum coke yielded $50-60 \mathrm{~mA} / \mathrm{cm}^{2}$ at $0.8 \mathrm{~V}$, and carbon blacks yielded $50-100 \mathrm{~mA} / \mathrm{cm}^{2}$ at $0.8 \mathrm{~V}$. Carbon aerogel microspheres showed good discharge characteristics, $90 \mathrm{~mA} / \mathrm{cm}^{2}$ at $0.8 \mathrm{~V}$. Carbon aerogels have unique properties of low crystallinity as demonstrated in the x-ray dimaction data, and high electrical conductivity. All the carbons studied had small primary particle sizes $(0.015-5 \mu \mathrm{m})$, and high specific surface areas $\left(0.4-1500 \mathrm{~m}^{2} / \mathrm{g}\right)$, but within these ranges particle size and surface area did not appear to affect the electrochemical discharge rate. The variance from $1.02 \mathrm{~V}$ at open circuit is likely due to the use of an argon purge gas in the anode chamber, necessitated by startup and standby conditions to avoid loss of carbon due to the Boudouard reaction. Under constant polarization, such a purge should not be necessary, but the conditions of these tests made it convenient to use a purge. It is known that having an argon atmosphere in the anode compartment may increase the open circuit potential in a configuration such as ours by $0.1-0.3 \mathrm{~V},{ }^{5,7}$ due to suppression of the $\mathrm{CO}_{2}$ concentration at the surface of the carbon (reducing the second term in Eq. 5).

Total resistivity of the working cells using Retec nickel foam electrodes is typically in the 5-6 ohm$\mathrm{cm}^{2}$ range, as determined from the slope of the polarization curves. Reference electrode measurements carried out during the experiments shown in Figure 2 show that properties of the carbons and the anode current collector make up $0.4-1.4 \mathrm{ohm}-\mathrm{cm}^{2}$ of the cell resistance, while the resistivity associated with the cathode is in the 2.5-2.8 ohm- $\mathrm{cm}^{2}$ range. The remainder, 2-2.5 ohm- $\mathrm{cm}^{2}$, is due to the IR drop across the zirconia separator. Measurements acquired with the carbon aerogel and the coal-derived activated carbon fuels are shown in Figure 3. The carbon aerogel cell polarization was $5.0 \mathrm{ohm}-\mathrm{cm}^{2}$, with a linear fit to the reference vs. anode and the reference vs. cathode data showing 0.4 and $2.5 \mathrm{ohm}-\mathrm{cm}^{2}$ respectively, the remainder, $2.1 \mathrm{ohm}-\mathrm{cm}^{2}$, is assumed to be due to the IR drop across the separator. Similarly, the coal-derived activated carbon had a cell polarization of $5.6 \mathrm{ohm}-\mathrm{cm}^{2}$; reference vs. anode and reference vs. cathode measurements were 0.6 and 2.8 ohm- $\mathrm{cm}^{2}$ respectively, with a $2.2 \mathrm{ohm}-\mathrm{cm}^{2}$ IR drop.

Therefore, although we do see variability among the particulate carbons, the contribution of the kinetics of reaction at the carbon anode is not controlling the discharge rate of our cells. This is a very significant finding, suggesting that power densities significantly higher than $100 \mathrm{~mW} / \mathrm{cm}^{2}$ may be achieved with an improved cathode. 
Primary particle size from electron microscopy. Representative scanning electron micrographs showing primary particle sizes are presented in Figure 4. The micrographs also give a good indication of connectivity of particles in aggregates, as well as extent of graphitization. It is worthwhile to note that some materials appear similar in the micrographs, for example the coconut-derived activated carbon, Arosperse 3, and acetylene black. However, their crystallinity index (from x-ray diffraction, discussed below) and electrochemical discharge characteristics (Figure 2) differ.

X-ray diffraction characterization of nanostructure. We employed X-ray scattering measurements in our study of the nine carbon samples, and carried out a detailed analysis of the resultant spectra. The spectra in the vicinity of the $\mathrm{d}(002)$ line are shown in Figure 5.

To obtain the d-spacing, the Bragg formula was used:

$$
d=\lambda /[2(\sin 2 \Theta / 2)]
$$

The full-width half-maximum (B) (in radians and corrected for instrument broadening) of Gaussian fits to the $d(110)$ and $d(002)$ lines were used to determine the crystallite dimensions, $L_{a}$ and $L_{c}$, respectively. Lattice strain may also have an effect on the line broadening. ${ }^{15}$

The linewidth (full-width half-maximum, FWHM) of each d(002) reflection was determined through background subtraction and subsequent fitting to a normal Gaussian function. The broader the linewidth, the less crystalline or graphitized the sample, with only very small domains of continuous crystallinity.

According to Kinoshita, ${ }^{15}$ the crystallite diameter, dimension $\mathrm{L}_{\mathrm{a}}$ in the plane of the layers (parallel to the basal plane) may be calculated using the broadening, $\mathrm{B}(110)$, of the $\mathrm{d}(110)$ linewidth:

$$
\mathrm{L}_{\mathrm{a}}=1.84 \lambda /(\mathrm{B}(110) \cdot \cos \Theta)
$$

The crystallite thickness, or layer dimension perpendicular to the basal plan of graphite $\mathrm{L}_{\mathrm{c}}$ may be estimated from the (002) reflection using the peak diffraction angle and the $\mathrm{d}(002)$ peak broadening, $\mathrm{B}(002)$ using the equation: ${ }^{15,16}$

$$
\mathrm{L}_{\mathrm{c}}=0.89 \lambda /(\mathrm{B}(002) \cdot \cos \Theta)
$$

Heat treatment studies show carbons that can grow in crystallite size from $\sim 1 \mathrm{~nm}$ to several thousand nanometers, and interlayer $\mathrm{d}$-spacing going from $\sim 0.39 \mathrm{~nm}$ to $0.335 \mathrm{~nm}$. The comprehensive crystallization index (CCI) defined by Fujimoto, et al. ${ }^{17}$ is:

$$
\mathrm{CCI}=\mathrm{f}_{\mathrm{D}} \cdot \mathrm{f}_{\mathrm{dc}} \cdot \mathrm{f}_{\mathrm{da}} \cdot \mathrm{f}_{\mathrm{Lc}} \cdot \mathrm{f}_{\mathrm{La}}
$$


Where $f_{D}$ is a density factor, $f_{D}=D / D^{0}\left(D^{0}\right.$ is the density of graphite, $\left.2.27 \mathrm{~g} / \mathrm{cm}^{3}\right), f_{d c}=d^{0}{ }_{002} / d_{002}\left(d^{0}{ }_{002}\right.$ is $0.3354 \mathrm{~nm}), \mathrm{f}_{\mathrm{da}}=\mathrm{d}_{110}{ }^{2} / \mathrm{d}^{0}{ }_{110}{ }^{2}\left(\mathrm{~d}^{0}{ }_{110}\right.$ is $\left.0.1230 \mathrm{~nm}\right) \mathrm{f}_{\mathrm{Lc}}=\mathrm{L}_{\mathrm{c}} / \mathrm{L}_{\mathrm{c}}+\mathrm{d}_{002}$ and $\mathrm{f}_{\mathrm{La}}=\mathrm{L}_{\mathrm{a}}{ }^{2} /\left(\mathrm{L}_{\mathrm{a}}+\mathrm{d}_{110}\right)^{2}$. We did not measure the density of samples, and therefore we come up with the $\mathrm{CCI} / \mathrm{f}_{\mathrm{D}}$ as a "crystallization index". Table 2 offers a summary of these calculations. The value of $\mathrm{CCI} / \mathrm{f}_{\mathrm{D}}$ was then converted to a rank, 1-9, and is listed alongside the electrochemical data, particle size and surface area data in Table 1.

Electrochemical performance of carbons is likely dependent on several characteristics, some of which counterbalance others. For example, less graphitized, disordered carbons such as chars are known to be very reactive to oxidation, due to a high concentration of edge atoms compared to those in the basal plane, however they are typically poorer electrical conductors. ${ }^{15}$ For example, thermogravimetric analysis (TGA) of air oxidation of graphitized Vulcan 3 (Cabot Corp., $63 \mathrm{~m}^{2} / \mathrm{g}$ ) shows a rate of $3.2 \times 10^{-6} \mathrm{~g} / \mathrm{m}^{2}$, while nongraphitized Monarch 700 (Cabot Corp., $206 \mathrm{~g} / \mathrm{m}^{2}$ ) oxidizes at $2.4 \times 10^{-4} \mathrm{~g} / \mathrm{m}^{2}{ }^{18}$ Graphitic carbons are very conductive, and therefore may perform well as electrochemical fuels due to enhanced charge transport, even though they are relatively less reactive chemically. We assume properties of carbons that change during consumption in the cell, such as surface groups or secondary aggregates of primary particles, are not relevant. This assumption is based on the observation that during dissolution and power generation over time (typically discharge was at a fairly constant voltage at constant current, sometimes with a slight gradual decline in voltage, until fuel was depleted) changes in electrochemical performance would be observed if these properties were significant. However, among the samples tested, neither variations among the samples in primary particle size, surface area, nor micromorphology are found to have a cumulative effect greater than about a factor of two on carbon fuel performance.

Scale-up. A cell with $60 \mathrm{~cm}^{2}$ active area and having the electrode assembly tilted $45^{\circ}$ from horizontal was assembled and tested (Figure 6). Overall cell resistivity using Acetylene Black and Needle Petroleum Coke fuels was 5.5 and $7.1 \mathrm{ohm}-\mathrm{cm}^{2}$ respectively. These values are comparable to the data acquired with 2.8 $\mathrm{cm}^{2}$ test cells, 5.0 and $8.1 \mathrm{ohm}-\mathrm{cm}^{2}$ for Acetylene Black and Needle Petroleum Coke, respectively. The anodic contribution to the overall cell polarization is small, as shown by the reference electrode measurements in Figure 7, for Needle Petroleum Coke at the 2.8- or $60-\mathrm{cm}^{2}$ scale, it is about $1.4 \mathrm{ohm}-\mathrm{cm}^{2}$. The $60 \mathrm{~cm}^{2}$ cell was cooled to room temperature between experiments, with no adverse effects on cell components or operation characteristics.

Long-term power generation. Long-term runs at constant current and temperature were acquired for many of the carbon samples. In some cases, voltage declined gradually during runs of 5-48 hours. These declines in voltage were sometimes reversible upon agitation within the anode compartment, refueling (under 
low fuel conditions) or addition of carbonate electrolyte (due to electrolyte loss). Figure 8 shows an experiment with the carbon aerogel microspheres, operating at constant current, $800{ }^{\circ} \mathrm{C}$, and constant voltage over about 30 hours. Utilization of the carbon fuel for this experiments could not be accurately estimated, because of the long standby intervals (up to 11 hours) before the start of polarization experiments and between polarization runs. During this time, an unmeasured amount of carbon was lost as a consequence of reaction oxygen on the original sample or reaction with air inadvertently leaked into the system. Carbon fuel loss occurs whenever carbon is either not in physical contact with the porous current collector, or when the cell is at open circuit and the carbon not polarized. In both cases, carbon will be lost via the Boudouard reaction. Considering the simplicity of the test cell, we expect that a specially engineered cell, under controlled operating conditions, kept polarized at all times, should approach the theoretical carbon utilization of $100 \%$.

Improved cathode for higher power densities. Figure 9 (top) shows the performance of the proprietary cathode material. With Arosperse 3 furnace black fuel (Sample 5), a three-day test was run. The overall cell resistivity, $2.6 \mathrm{ohm}-\mathrm{cm}^{2}$ on day one, increasing slightly to $3.2 \mathrm{ohm}-\mathrm{cm}^{2}$ by day three is somewhat better than that observed using a nickel foam cathode, about $5 \mathrm{ohm}-\mathrm{cm}^{2}$. Also, Figure 9 (top) shows that the power output declines by about a factor of two between operating temperature 800 and $700{ }^{\circ} \mathrm{C}$. This is typical for the carbon fuels we tested, and not strongly dependent on the cathode employed. Another fuel, needle petroleum coke was also tested with the proprietary cathode, demonstrating a similar improvement of about a factor of two in overall cell resistivity, from $8.1 \mathrm{ohm}-\mathrm{cm}^{2}$ using a nickel foam cathode to $3.9 \mathrm{ohm}-\mathrm{cm}^{2}$ using the proprietary cathode. Further exploration into preparation of high-performance electrodes resulted in our fabrication of a special multilayer design, having a fine-grained, porous nickel layer in combination with a thicker, larger grained nickel support structure. This electrode design is very promising, and its performance appears in Figure 9 (bottom) to have slightly better characteristics than the proprietary cathode, with a cell resistivity of about $2.4 \mathrm{ohm}-\mathrm{cm}^{2}$ using Arosperse 3 fuel. Also, it shows good thermal cycling behavior, with very little decline in performance over 3 runs, cooling to room temperature between runs.

Effects of impurities on discharge. Many inexpensive and readily available carbon fuels, such as coal and petroleum coke are contaminated with sulfur and ash. We therefore studied a petroleum coke from Conoco containing $2.86 \mathrm{wt} \%$ sulfur, $0.5 \mathrm{wt} \%$ volatiles and $0.28 \mathrm{wt} \%$ ash. Our experience with cokes containing 2.5-6 wt \% sulfur indicates that sulfidation corrosion at the anode degrades cell performance over time. Figure 10 shows a two-day experiment with the Conoco coke, using a proprietary cathode. On day one, the overall cell resistance is $6.1 \mathrm{ohm}-\mathrm{cm}^{2}$, and by day two, the resistivity increased to $9.3 \mathrm{ohm}-\mathrm{cm}^{2}$. It is interesting to note the increased open circuit voltage from day one to day two - we have observed this with 
other relatively graphitized materials, but at this time we have no explanation for this phenomenon. The discharge rate of the Conoco coke is also lower $\left(34 \mathrm{~mW} / \mathrm{cm}^{2}\right.$ peak power) than that of the needle petroleum coke $\left(82 \mathrm{~mW} / \mathrm{cm}^{2}\right.$ peak power), which is low in contaminants. The data shown in Figure 10 is typical of several Conoco coke samples with impurity levels of 2.5-6 wt \% sulfur and 0.2-0.7 wt \% ash that we have tested. Nickel in a high sulfur environment is very susceptible to corrosion, especially in a reducing environment. ${ }^{19}$ In-situ reactions to form nickel sulfides seem to significantly alter the porous electrode structure, resulting in densification and thus poorer contact with the particulate carbon and diminished current collection capacity. With a sulfidation corrosion resistant anode current collector, it is likely that sustained power densities in the $40-50 \mathrm{~mW} / \mathrm{cm}^{2}$ range can be achieved with some of the least expensive carbon fuelshigh sulfur cokes and coals.

Physical Model Relating Structure to Reactivity and $\mathrm{CO}_{2}$ Reaction Product. The anodic reaction of carbon has been widely studied for basic melts (carbonates) as well as acidic melts (cryolite). We suggest that the mechanisms might be similar. In both cases, the anodic reaction at high rates results in the predominant formation of $\mathrm{CO}_{2}$. For temperatures above $650{ }^{\circ} \mathrm{C}$, the Boudouard equilibrium $\left(\mathrm{C}+\mathrm{CO}_{2} \rightarrow 2 \mathrm{CO}\right)$ would predict that $\mathrm{CO}$ would predominate. Haupin and Frank ${ }^{10}$, and Frank, et al. ${ }^{20}$ of Alcoa summarized the mechanism [10-16], initiated by the dissociation of an aluminofluirde species to form a free oxide ion. This ion adsorbs on the surface and is discharged in two 1-electron steps to form a strongly bound CO functional group at reactive carbon sites (such as edges or steps). This functional group will decompose to form only free CO very slowly.

A second adsorption of oxide onto the $\mathrm{C}_{\mathrm{RS}} \mathrm{O}$ site [14] is kinetically hindered, requires considerable overpotential and constitutes the rate-determining step for carbon oxidation to $\mathrm{CO}_{2}$. Subsequent discharge of this adsorbed species occurs in two 1-electron transfers $[13,14]$ to form an unstable group $\mathrm{C}_{\mathrm{RS}} \mathrm{O}_{2}$ that is readily desorbed as $\mathrm{CO}_{2}$. Support for this model comes from the earlier experimental work of Thonstad, ${ }^{9}$ who measured Tafel slopes in cryolite melts and found them to be too great for the rate-determining step to involve an electron transfer and measured a subunity reaction order for oxide concentration. Such a dependence is consistent with reaction control involving a slow, heterogeneous absorption step, as discussed by Vetter ${ }^{21}$.

$$
\begin{array}{ll}
2\left[\mathrm{Al}_{2} \mathrm{O}_{2} \mathrm{~F}_{4}\right]^{2} \rightarrow 2 \mathrm{O}^{2-}+2 \mathrm{Al}_{2} \mathrm{OF}_{4} & \\
\mathrm{C}_{\mathrm{RS}}+\mathrm{O}^{2-} \rightarrow \mathrm{C}_{\mathrm{RS}} \mathrm{O}^{2-} & \text { first adsorption } \\
\mathrm{C}_{\mathrm{RS}} \mathrm{O}^{2-} \rightarrow \mathrm{C}_{\mathrm{RS}} \mathrm{O}^{-}+\mathrm{e}^{-} & \text {fast discharge } \\
\mathrm{C}_{\mathrm{RS}} \mathrm{O}^{-} \rightarrow \mathrm{C}_{\mathrm{RS}} \mathrm{O}+\mathrm{e}^{-} & \text {fast discharge }
\end{array}
$$




$$
\begin{array}{ll}
\mathrm{C}_{\mathrm{RS}} \mathrm{O}+\mathrm{O}^{2-} \rightarrow \mathrm{C}_{\mathrm{RS}} \mathrm{O}_{2}{ }^{2-} & \text { slow adsorption: RDS } \\
\mathrm{C}_{\mathrm{RS}} \mathrm{O}_{2}{ }^{2-} \rightarrow \mathrm{C}_{\mathrm{RS}} \mathrm{O}_{2}^{-}{ }^{-} \mathrm{e}^{-} & \text {fast discharge } \\
\mathrm{C}_{\mathrm{RS}} \mathrm{O}_{2}^{-} \rightarrow \mathrm{CO}_{2}(\mathrm{~g})+\mathrm{e}^{-} & \text {fast discharge and evolution }
\end{array}
$$

Since the carbonate salts show a strong dissociation at $700{ }^{\circ} \mathrm{C}$ (yielding a mole fraction of oxide of $10^{-4}$ for the tri-eutectic), it is reasonable to replace [10] in Hall model with [17]

$$
2 \mathrm{CO}_{3}{ }^{2-} \rightarrow 2 \mathrm{CO}_{2}+2 \mathrm{O}^{2-}
$$

Reactions [11-17] lead to the net reaction observed for carbon anode in molten carbonate melts [18]:

$$
\mathrm{C}_{\mathrm{RS}}+2 \mathrm{CO}_{3}{ }^{2-} \rightarrow 3 \mathrm{CO}_{2}+4 \mathrm{e}^{-}
$$

$\mathrm{C}_{\mathrm{RS}}$ is a carbon atom at a reactive site at an edge, defect, step or other surface imperfection in an otherwise stable graphene plane. Carbon materials high in defects and low in crystallinity are most reactive, as verified in this study.

The electrons released by the anodic reaction must first be conducted to the anode current collector to generate an external current. Carbon materials high in electrical conductivity will allow larger areas of the particle (at greater distances from the point of electron transfer to the current collector) to be sufficiently polarized to undergo a $4 \mathrm{e}^{-}$net transfer of reaction [18]. For a given current density, the total anode polarization is the sum of internal ohmic losses and surface overpotential; larger ohmic losses means a lowered surface overpotential and an increased rate of corrosion by ambient $\mathrm{CO}_{2}$.

The electrical conductivity of highly graphitized particulate carbon is known to be 3-4 times greater than that of the least graphitized carbons. ${ }^{22}$ While surface area was not found to have a strong effect on the rate of carbon discharge, all the carbons studied were particulate and had high surface area $\left(0.4-1225 \mathrm{~m}^{2} / \mathrm{g}\right)$. It is expected that graphitized carbon samples with low surface area would show lower discharge rates, as reactive sites become limited. In summary, the properties of carbon fuels which control their rate of discharge in molten electrolyte are: (1) crystallographic disorder - the less graphitic carbons, as evidenced by a low crystallization index are the more reactive, both chemically and electrochemically; (2) electrical conductivity — due to cell design, reaction of particulate carbons may occur out of direct electrical contact with the metal current collector, and the conductivity of the carbon itself facilitates current collection (electron transport); and (3) adequate reactive surface sites (mass transport). 


\section{Acknowledgements}

We gratefully acknowledge the Energy and Environment Directorate for support of this research under the Laboratory Directed Research and Development Program (LDRD). Thanks to David Ahre and Mark Fowler for machining and mechanical assistance, to Jim Ferreira and Cheng Saw for their respective electron microscopy and x-ray diffraction support, to Tom Tillotson for carbon aerogel samples, to Robert Hopper for his literature searches, and to Kim Kinoshita for various carbon samples and guidance. This work was performed under the auspices of the U.S. Department of Energy by the University of California, Lawrence Livermore National Laboratory under contract No. W-7405-Eng-48. 


\section{References}

1. DOE Energy Information Administration data for 2000 and 2001, http://www.eia.doe.gov/oiaf/aeo/tbl1.html.

2. J. F. Cooper, N. Cherepy, G. Berry, A. Pasternak, and T. Surles, "Direct Carbon Conversion: Application to the Efficient Conversion of Fossil Fuels to Electricity," (Proc. Global Warming Conference, PV 202000, The Electrochemical Society April, 2001.)

3. H. A. Liebhafsky and E. J. Cairns, Fuel Cells and Fuel Batteries, John Wiley and Sons, New York, NY (1968).

4. V.E. Hauser Jr., A Study of Carbon Anode Polarization in Fused Carbonate Fuel Cells, Ph.D. Dissertation, Oregon State Univ. (1964).

5. J. Dubois, J. Millet and S. Palous, Electrochem., Acta, 12, 241 (1967).

6. R.D. Weaver, S.C. Leach, A.E. Bayce and L. Nanis, Direct Electrochemical Generation of Electricity from Coal, SRI, Menlo Park, CA 94025; SAN-0115/105-1; available from NTIS (1979).

7. D.G. Vutetakis, D.R. Skidmore, H.J. Byker, J. Electrochem. Soc. 134, 3027 (1987); See also D.G. Vutetakis, Electrochemical oxidation of carbonaceous materials dispersed in molten salt, Ph.D. Dissertation, Ohio State University, Columbus OH (1985).

8 T. M. Gur and R. A. Huggins, J. Electrochem. Soc. 139, L-95, 1992.

9. J. Thonstad, Electrochim. Acta, 15, 1569 (1970).

10. W. E. Haupin, W.B. Frank, Electrometallurgy of Aluminum in Comprehensive Treatise of Electrochemistry, Vol. 2, Electrochemical Processing, J. O’M. Bockris, B.E. Conway, E. Yeager, R.E. White Eds., Plenum Press, New York, 301-325 (1981).

11. N. Cherepy, R. Krueger, J.F. Cooper, Proc. Electrochem. Soc., PV 2000-22, (2000).

12. S.T. Mayer, F.M. Kong, R.W. Pekala, J.L. Kaschmitter, Organic Aerogel Microspheres, US Patent 5908896.

13. R. J. Pekala, Mat. Sci., 24, 3221 (1989).

14. Borucka, and C.M. Sugiyama, Electrochim. Acta., 13, 1887 (1968). 
15. K. Kinoshita, Carbon: Electrochemical and Physicochemical Properties, John Wiley \& Sons, New York, NY (1988).

16. M. S. Dresselhaus, G. Dresselhaus, K. Sugihara, I. L. Spain \& H. A. Goldberg, Graphite Fibers and Filaments, Springer-Verlag, Berlin (1988).

17. H. Fujimoto, K. Tokumitsu, A. Mabuchi \& T. Kasuh, Carbon, 32, 1249 (1994).

18. L. R. Radovich, P.L. Walker, R.G. Jenkins, Fuel, 62, 849 (1983).

19. J.R. Crum, E. Hibner, N.C.Farr \& D.R. Munasinghe, Nickel-Based Alloys in Practical Handbook of Stainless Steels \& Nickel Alloys, S. Lamb, J.E. Bringas, Eds., CASTI Publishing, Edmonton, Alberta, CA, (1999).

20. Klaus J. Vetter, Electrochemical Kinetics: Theoretical and Experimental Aspects, Academic Press, New York (1967).

21. W. B. Frank, W. E. Haupin, et al., Ullmann's Encyclopedia of Industrial Chemistry, 5th Edition, A1, Aluminum (1985).

22. P.L Walker, American Scientist, June, (1962). 
Table 1. Summarized properties of tested carbons.

\begin{tabular}{|c|c|c|c|c|c|c|}
\hline & Sample & $\begin{array}{l}\text { Surface } \\
\text { Area }^{a} \\
\left(\mathrm{~m}^{2} / \mathrm{g}\right)\end{array}$ & $\begin{array}{c}\text { Primary } \\
\text { Particle Size }^{b} \\
(\mathbf{n m})\end{array}$ & $\begin{array}{l}\text { Crystallinity } \\
\text { Parameter }^{\mathrm{c}} \\
\text { (rank) }\end{array}$ & $\begin{array}{c}\mathrm{I}^{\mathrm{d}}(\mathrm{mA} / \\
\left.\mathrm{cm}^{2}\right) \mathrm{at} \\
0.8 \mathrm{~V}\end{array}$ & $\begin{array}{c}\text { Peak } \\
\text { Power }^{\mathrm{e}} \\
\mathbf{E}^{2} / 4 \mathrm{R} \\
\left(\mathrm{mW} / \mathrm{cm}^{2}\right)\end{array}$ \\
\hline 1 & $\begin{array}{l}\text { Peach Pit AW } \\
\text { activated carbon }\end{array}$ & $>1000$ & $30-3000$ & 8 & 124 & 84 \\
\hline 2 & $\begin{array}{l}\text { Coconut act. } \\
\text { carbon, AW, } \\
\text { milled }\end{array}$ & 1050 & $\begin{array}{c}20 \\
\text { spheres }\end{array}$ & 7 & 102 & 56 \\
\hline 3 & $\begin{array}{l}\text { Coal-derived act. } \\
\text { carbon, AW, } \\
\text { milled }\end{array}$ & 950 & $60-10000$ & 6 & 65 & 51 \\
\hline 4 & $\begin{array}{l}\text { Acetylene Black } \\
\text { (from acetylene } \\
\text { pyrolysis) }\end{array}$ & 75 & $\begin{array}{c}40 \\
\text { spheres }\end{array}$ & 3 & 77 & 61 \\
\hline 5 & $\begin{array}{l}\text { Arosperse } 3 \\
\text { (from furnace oil) }\end{array}$ & 75 & $\begin{array}{c}30 \\
\text { spheres }\end{array}$ & 5 & 110 & 39 \\
\hline 6 & $\begin{array}{l}\text { Carbon aerogel } \\
\text { microspheres, } \\
\text { pyrolyzed } \\
1050^{\circ} \mathrm{C} \text { (glassy } \\
\text { carbon) }\end{array}$ & 1225 & $\begin{array}{l}20000- \\
100000 \\
\text { porous } \\
\text { spheres }\end{array}$ & 9 & 87 & 61 \\
\hline 7 & $\begin{array}{l}\text { Arosperse } 15, \\
\text { thermal black } \\
\text { (from methane } \\
\text { pyrolysis) }\end{array}$ & 9 & $\begin{array}{c}290 \\
\text { spheres }\end{array}$ & 4 & 47 & 46 \\
\hline 8 & $\begin{array}{l}\text { Needle } \\
\text { Pet. Coke, } \\
\text { calcined } 1400^{\circ} \mathrm{C} \text {, } \\
\text { milled }\end{array}$ & 0.4 & $\begin{array}{c}3000-100000 \\
\text { needles }\end{array}$ & 2 & 58 & 36 \\
\hline 9 & $\begin{array}{l}\text { Desulco Graphite } \\
\text { particles }\end{array}$ & 9 & $\begin{array}{c}\text { 5000-30000 } \\
\text { stacked } \\
\text { sheets }\end{array}$ & 1 & 58 & 46 \\
\hline
\end{tabular}

${ }^{\text {a }}$ Surface area provided by supplier.

${ }^{\mathrm{b}}$ Primary particle size determined from scanning electron microscope images.

${ }^{\mathrm{c}}$ Crystallinity rank determined from the comprehensive crystallization index and listed from most crystalline, \#1 to least crystalline, \#9. See Table 2 for further details.

${ }^{\mathrm{d}}$ Current density is measured in an operating carbon/air cell at $0.8 \mathrm{~V}$ anode to cathode potential difference.

${ }^{\mathrm{e}}$ Peak Power calculation uses $1.02 \mathrm{~V}$ for the potential, E, and the resistivity calculated from a linear fit to

the current/voltage curve. 
Table 2. Crystallization index determination for carbon samples.

\begin{tabular}{|l|l|c|c|c|c|c|c|}
\hline & Sample & $\begin{array}{c}\mathbf{d}(\mathbf{0 0 2}) \\
(\mathbf{n m})\end{array}$ & $\begin{array}{c}\mathbf{d}(\mathbf{1 1 0}) \\
(\mathbf{n m})\end{array}$ & $\begin{array}{c}\mathbf{L}_{\mathbf{a}} \\
(\mathbf{n m})\end{array}$ & $\begin{array}{c}\mathbf{L}_{\mathbf{c}} \\
(\mathbf{n m})\end{array}$ & $\mathbf{C C I} / \mathbf{f}_{\mathbf{D}}$ & $\begin{array}{c}\text { Cryst. } \\
\text { Rank }\end{array}$ \\
\hline 1 & $\begin{array}{l}\text { Peach Pit activated } \\
\text { carbon, AW }\end{array}$ & 0.385 & 0.1205 & 2.86 & 1.01 & 0.558 & 8 \\
\hline 2 & $\begin{array}{l}\text { Coconut act carbon, AW, } \\
\text { milled }\end{array}$ & 0.379 & 0.1205 & 2.93 & 0.981 & 0.565 & 7 \\
\hline 3 & $\begin{array}{l}\text { Coal-derived act carbon, } \\
\text { AW, milled }\end{array}$ & 0.359 & 0.1204 & 2.88 & 1.33 & 0.649 & 6 \\
\hline 4 & $\begin{array}{l}\text { Acetylene Black, from } \\
\text { acetylene }\end{array}$ & 0.359 & 0.1213 & 4.27 & 2.51 & 0.696 & 3 \\
\hline 5 & $\begin{array}{l}\text { Arosperse 3, from furnace } \\
\text { oil }\end{array}$ & 0.364 & 0.1205 & 2.96 & 1.45 & 0.652 & 5 \\
\hline 6 & $\begin{array}{l}\text { Carbon aerogel } \\
\text { microspheres, pyrolyzed } \\
\text { at } 10500^{\circ} \mathrm{C}\end{array}$ & 0.389 & 0.1200 & 3.15 & 0.975 & 0.545 & 9 \\
\hline 7 & $\begin{array}{l}\text { Arosperse 15, thermal } \\
\text { black, from methane }\end{array}$ & 0.367 & 0.1208 & 3.45 & 1.65 & 0.665 & 4 \\
\hline 8 & $\begin{array}{l}\text { Needle Pet. Coke, } \\
\text { calcined at } 1400^{\circ} \mathrm{C},\end{array}$ & 0.351 & 0.1217 & 5.21 & 4.03 & 0.821 & 2 \\
\hline 9 & $\begin{array}{l}\text { Desulco Graphite } \\
\text { particles }\end{array}$ & 0.337 & 0.1233 & 19.3 & 22.4 & 0.972 & 1 \\
\hline
\end{tabular}




\section{Figure Captions}

Figure 1. A schematic representation of the carbon/air molten carbonate cell, built inside an alumina tube and contained within an alumina crucible. The cathode and anode are made of porous nickel, with a zirconia cloth separator.

Figure 2. Polarization curves for 9 samples acquired in a $2.8 \mathrm{~cm}^{2}$ cell at $800^{\circ} \mathrm{C}$ using the $\mathrm{Li} / \mathrm{K}$ eutectic electrolyte, nickel foam electrodes, and zirconia cloth separator. All experiments conducted using Argon as a purge gas in the anode chamber, and 5:2 air/ $\mathrm{CO}_{2}$ ratio in the cathode chamber.

Figure 3. Reference electrode measurements are shown for two samples, Carbon Aerogel and Coal-derived Activated Carbon. For both carbons, the reference vs. anode measurement shows much less polarization than the reference vs. cathode measurement.

Figure 4. Scanning electron micrographs of the nine carbon samples indicates wide variability in primary particle size and aggregation. (a) Sample 1, Peach Pit Activated Carbon, (b) Sample 2, Coconut Activated Carbon, (c) Sample 3, Coal-derived Activated Carbon, (d) Sample 4, Acetylene Black (e) Sample 5, Arosperse 3, (f) Sample 6, Carbon Aerogel (g) Sample 7, Arosperse 15 (h) Sample 8, Needle Petroleum Coke, (i) Sample 9, Desulco Graphite particles

Figure 5. X-ray diffraction data for the eleven samples in the region of the $\mathrm{d}(002)$ line show varying degrees of graphitization.

Figure 6. The $60 \mathrm{~cm}^{2}$ cell generates $2.5-3 \mathrm{~W}$ peak power, at $\sim 0.8 \mathrm{~V}$ with Petroleum Coke or Acetylene Black fuels.

Figure 7. Data acquired of needle petroleum coke fuel using the $60 \mathrm{~cm}^{2}$ cell shows linear scaling of current and power densities compared to the $2.8 \mathrm{~cm}^{2}$ cell. Reference electrode measurements indicate that anode behavior for the two cells is the same, and the limitation is at the nickel foam cathode.

Figure 8. Long-term power generation is shown for a $2.8 \mathrm{~cm}^{2}$ cell experiment. The cell voltage is shown at time 0 (open circuit, $1.18 \mathrm{~V}$ ), at $54 \mathrm{~mA} / \mathrm{cm}^{2}$ for 1 hour, then the cell was held at $27 \mathrm{~mA} / \mathrm{cm}^{2}$ constant current for 30 hours, and had a very stable potential of $\sim 1 \mathrm{~V}$.

Figure 9. (Top) High-performance nickel cathodes demonstrate power densities of $\sim 100 \mathrm{~mA} / \mathrm{cm}^{2}$ for inexpensive carbon fuels, Arosperse 3 (furnace black) and petroleum coke. (Bottom) The LLNL high surface area cathode, consisting of submicron to $200 \mu \mathrm{m}$ pores, outperforms the proprietary cathode slightly. 
Figure 10. Conoco coke (2.86 wt $\%$ sulfur and $0.28 \mathrm{wt} \%$ ash) shows a discharge rate about $50 \%$ that of purified petroleum coke (Figure 9, top), using the proprietary cathode and a nickel foam anode. Increased cell resistivity over time is ascribed to sulfidation corrosion and densification of the anode.

Figure 11. Pictorial description of the electrochemical oxidation at the surface of a carbon electrode (after Haupin and Frank). ${ }^{10}$ (A) Initial oxygen deposits as $\mathrm{C}_{2} \mathrm{O}$, a stable surface compound. (B) As the surface becomes covered, $\mathrm{C}_{3} \mathrm{O}_{2}$ is formed, requiring additional energy (overvoltage). $\mathrm{C}_{3} \mathrm{O}_{2}$ cleaves easily, as indicated by the dotted line, releasing $\mathrm{CO}_{2}$ and new surface carbon atoms. 


\section{Figure 1.}

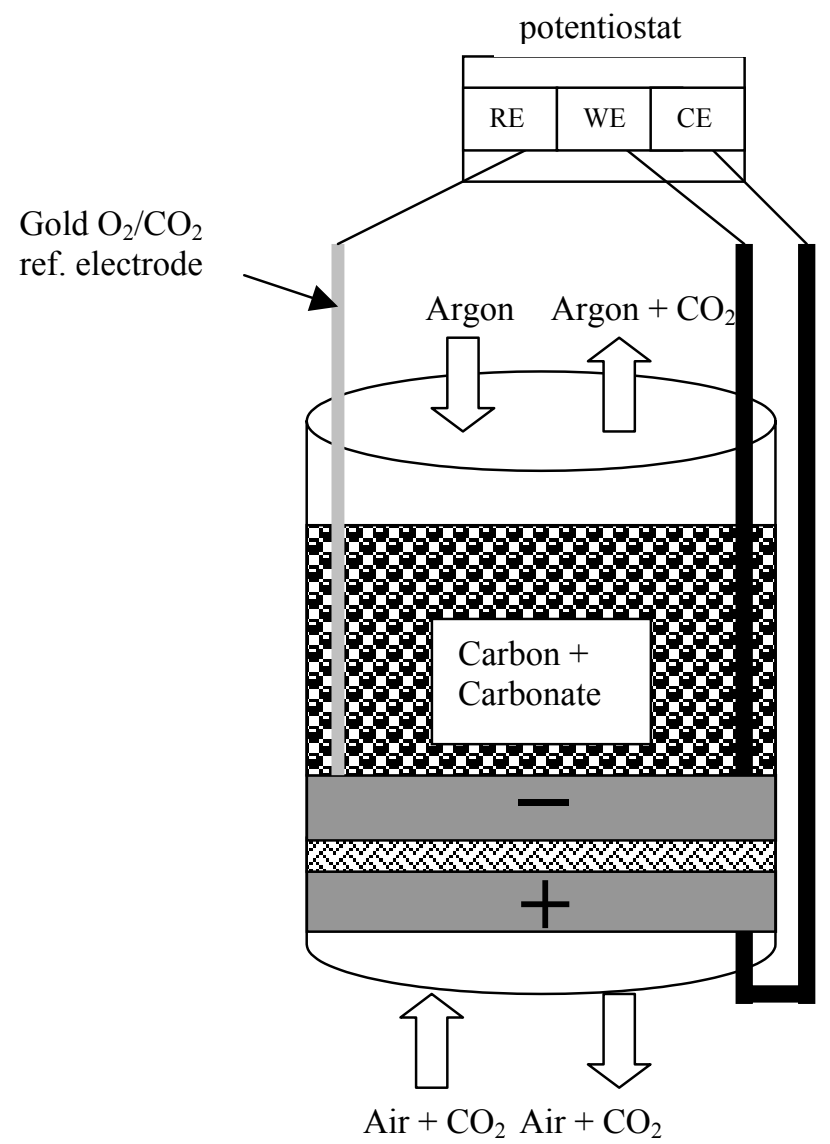


Figure 2.

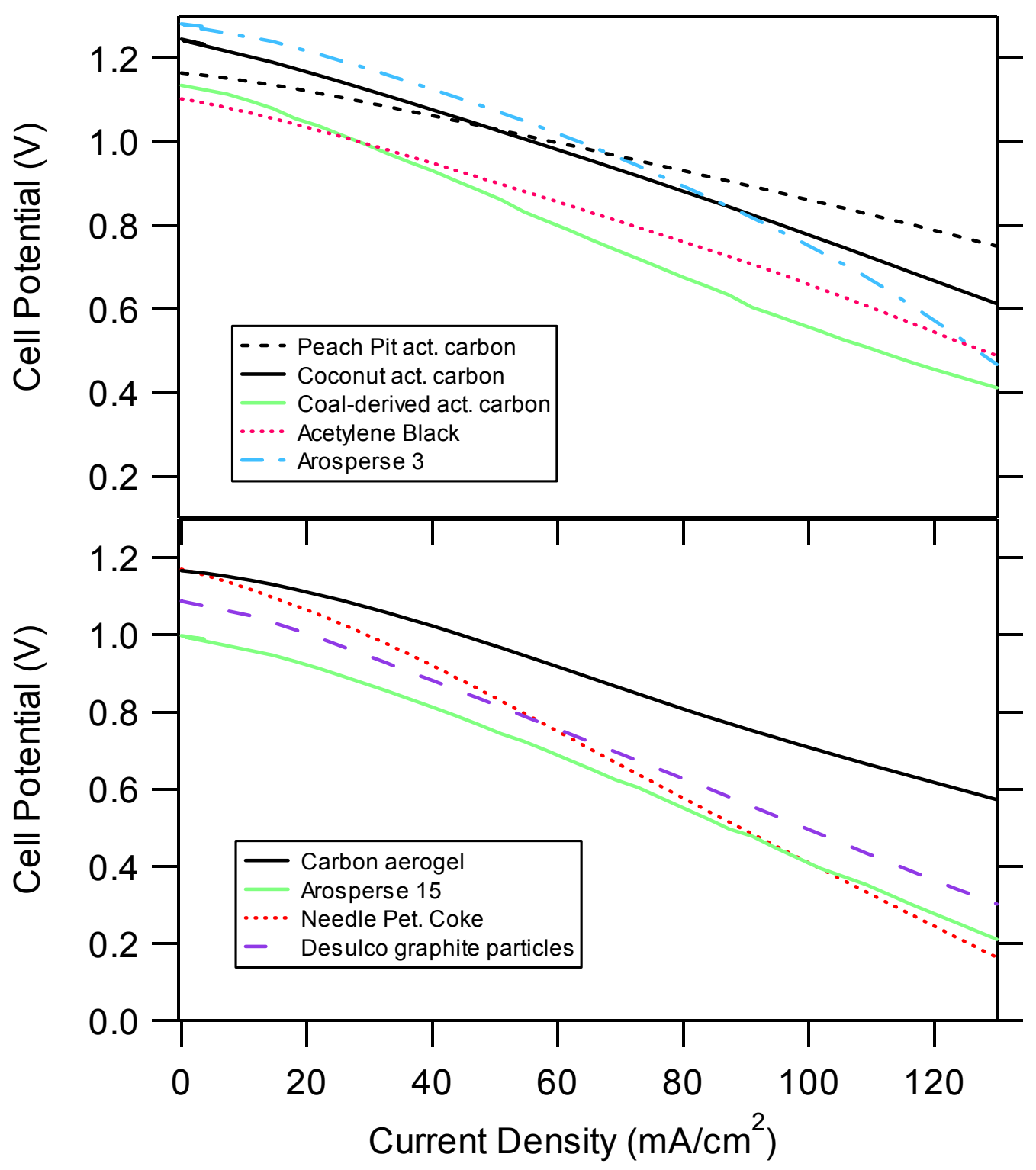


Figure 3.

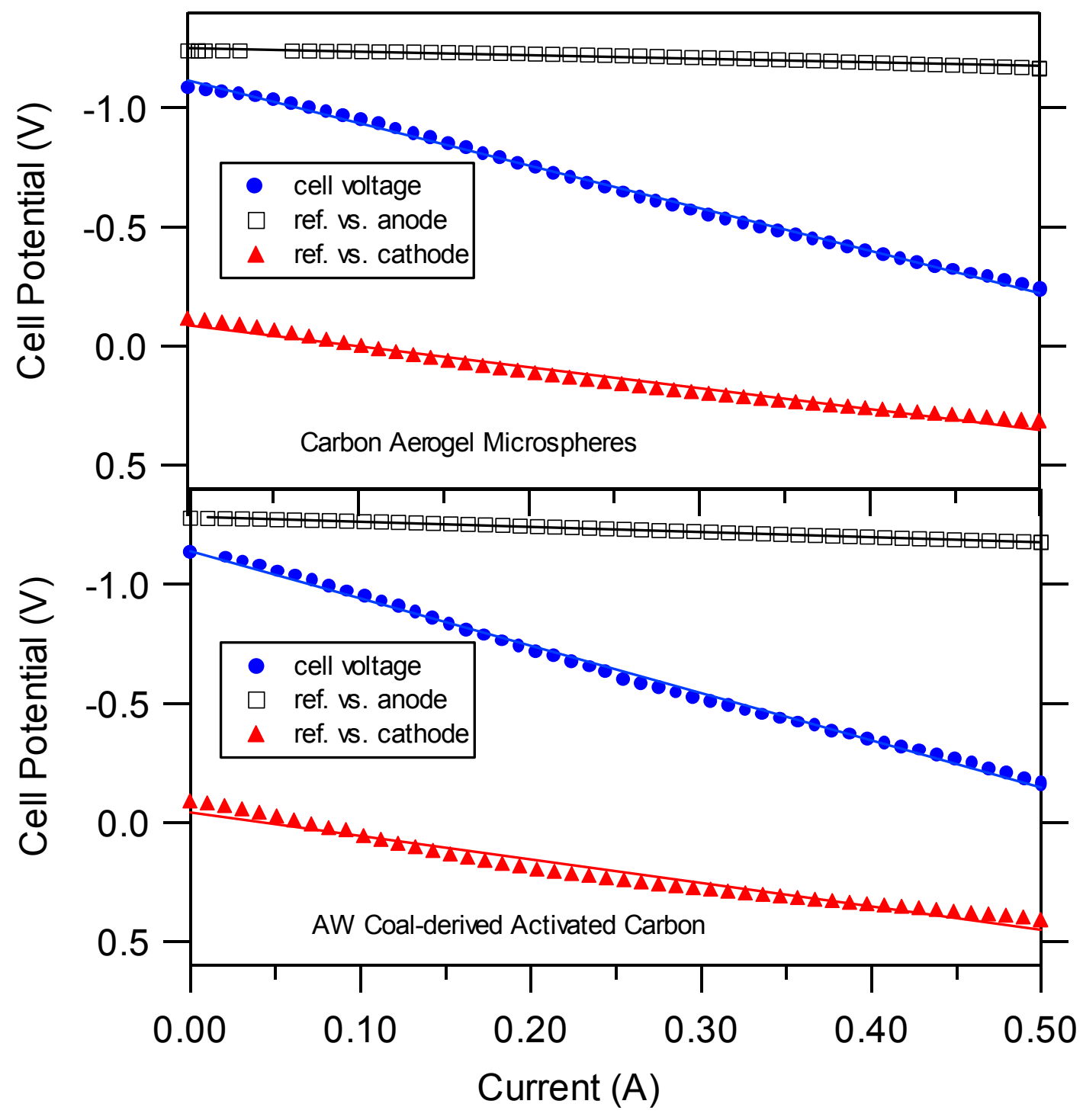


Figure 4.
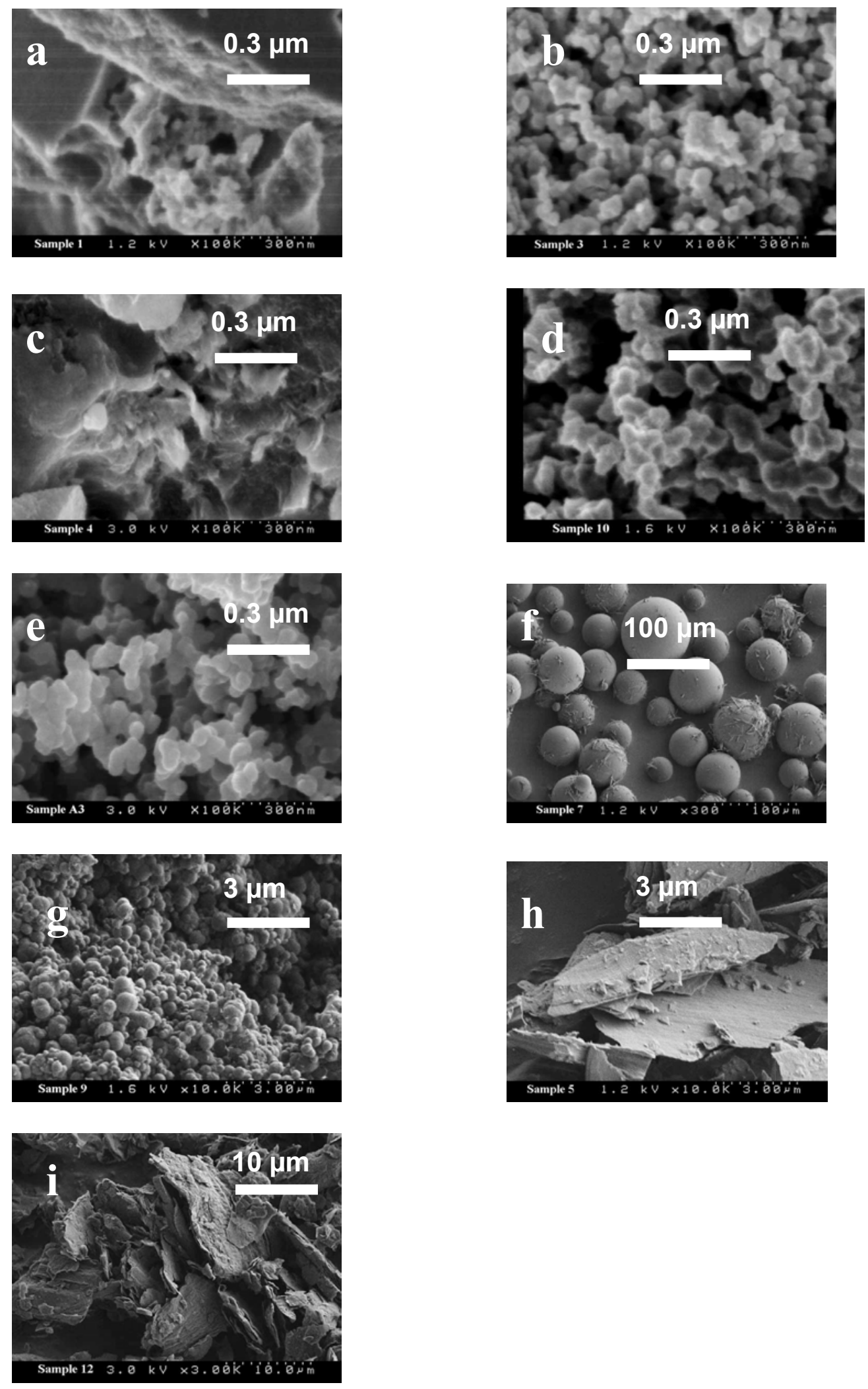


\section{Figure 5.}

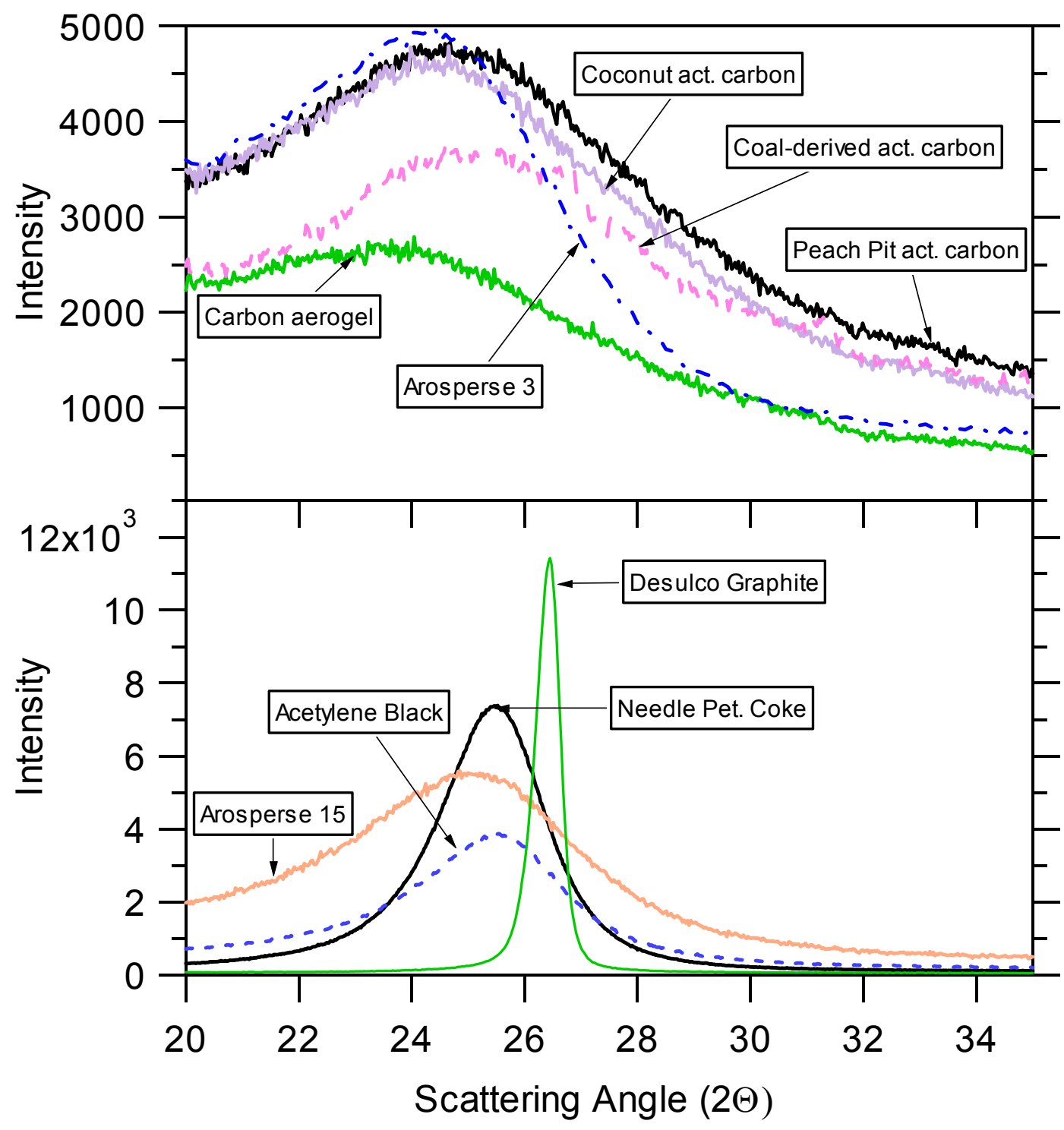


Figure 6.

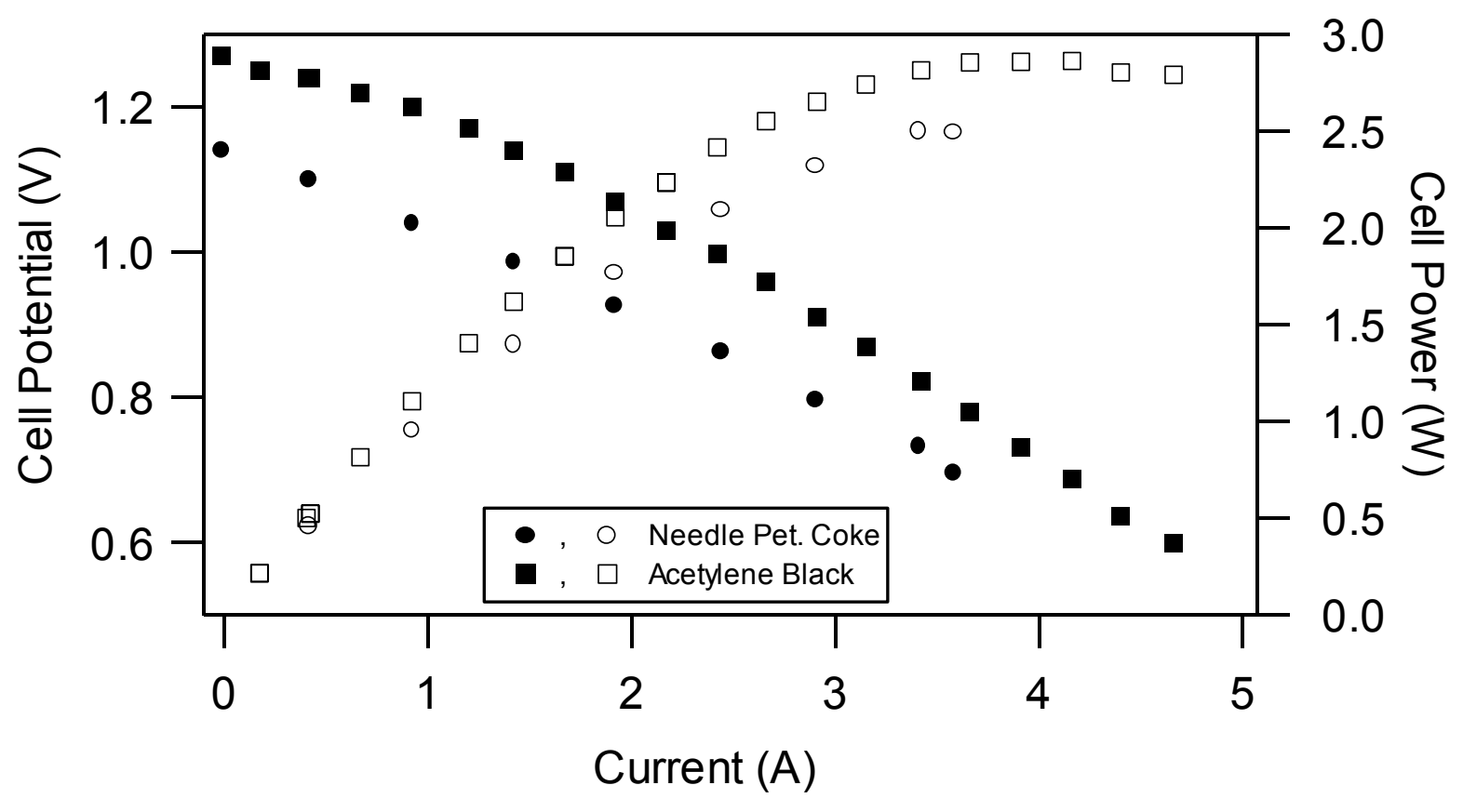


Figure 7.

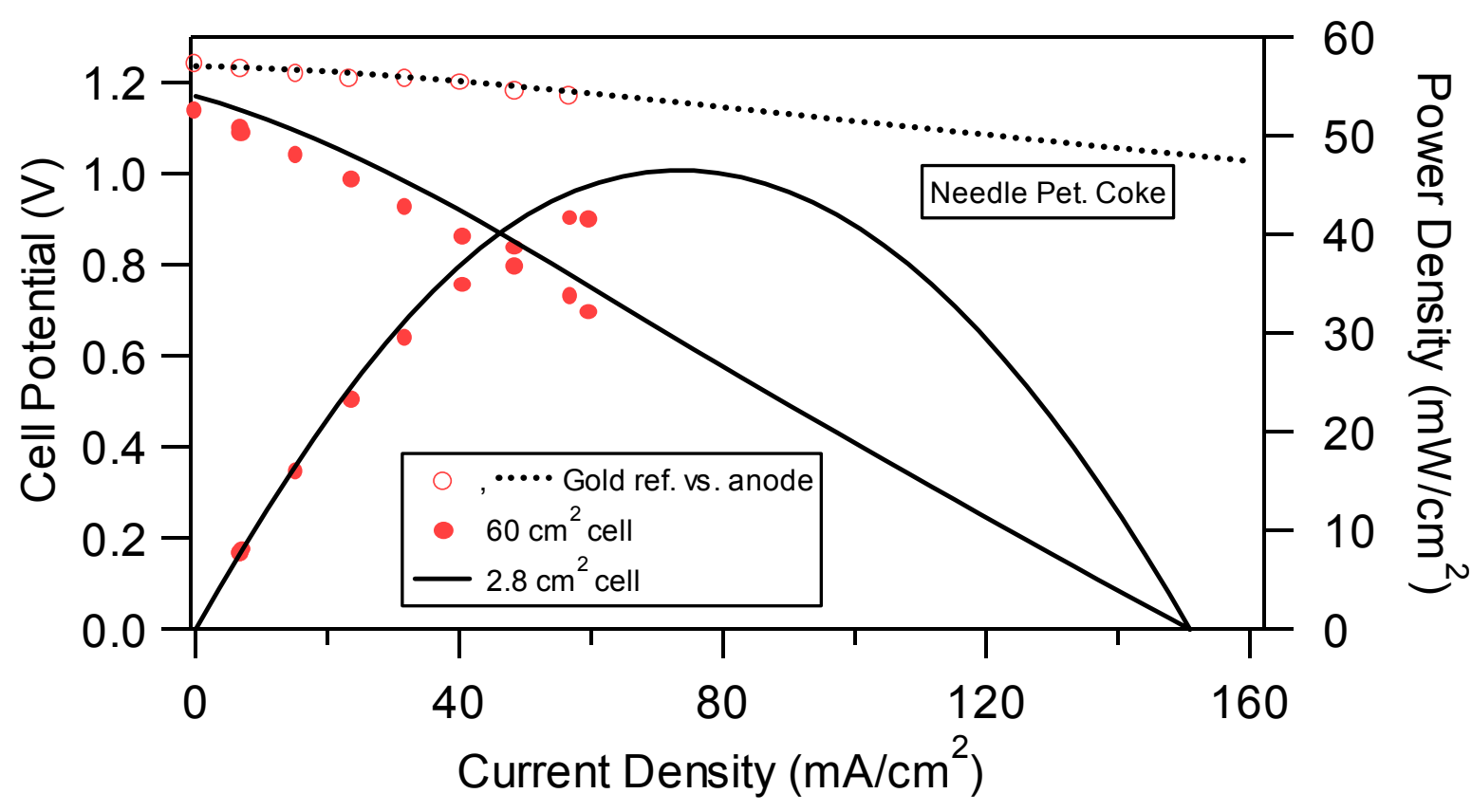


Figure 8.

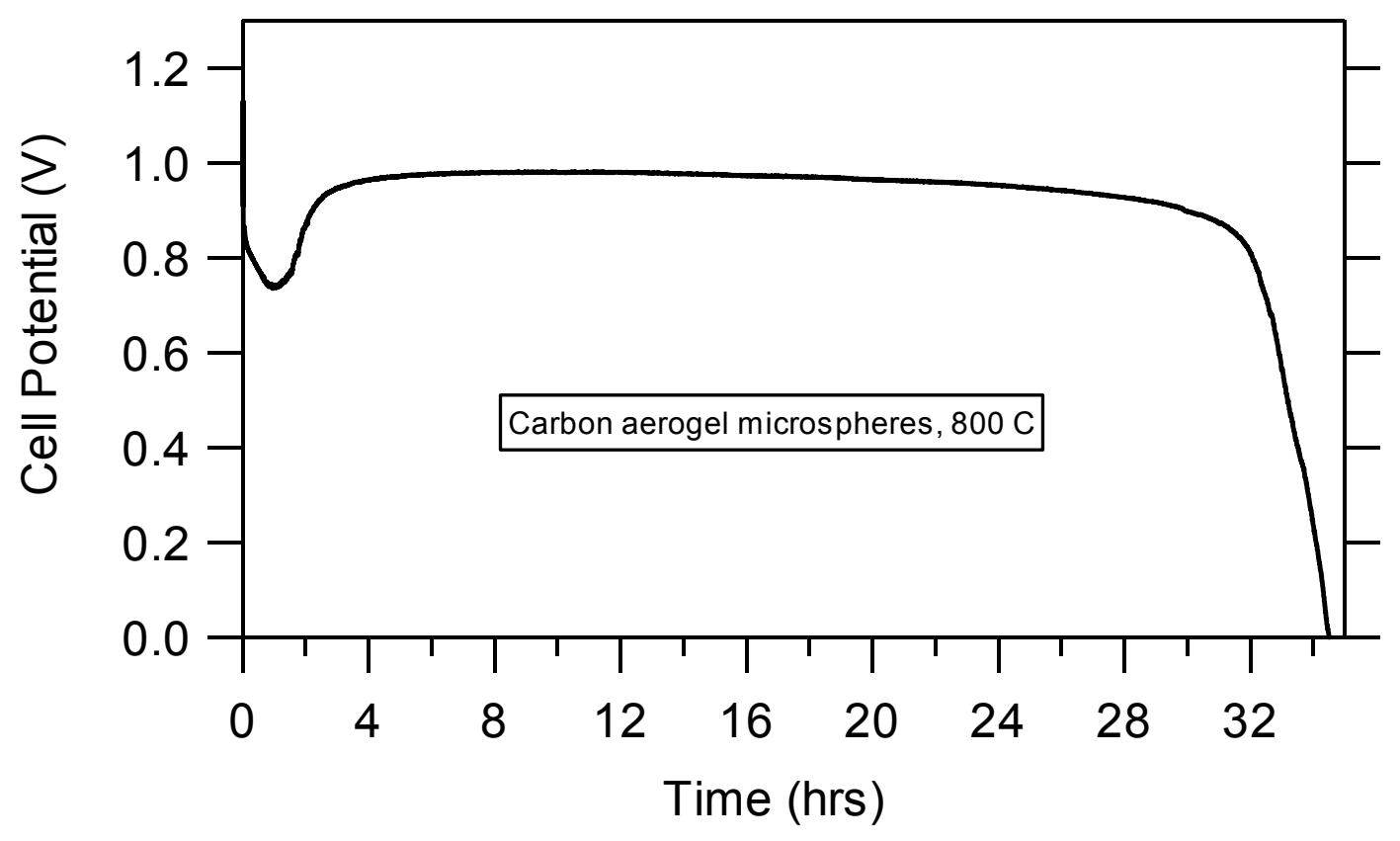


Figure 9.
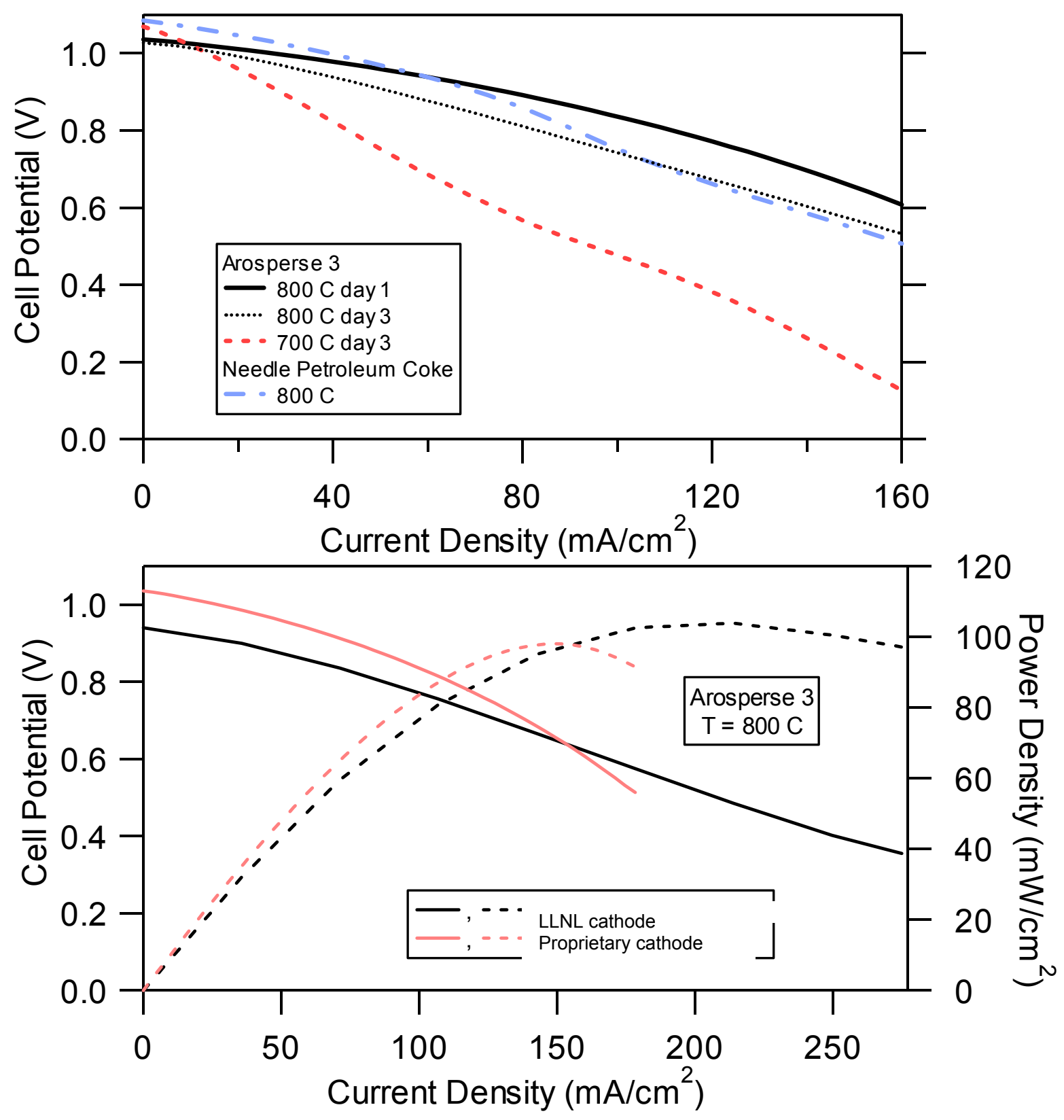
Figure 10.

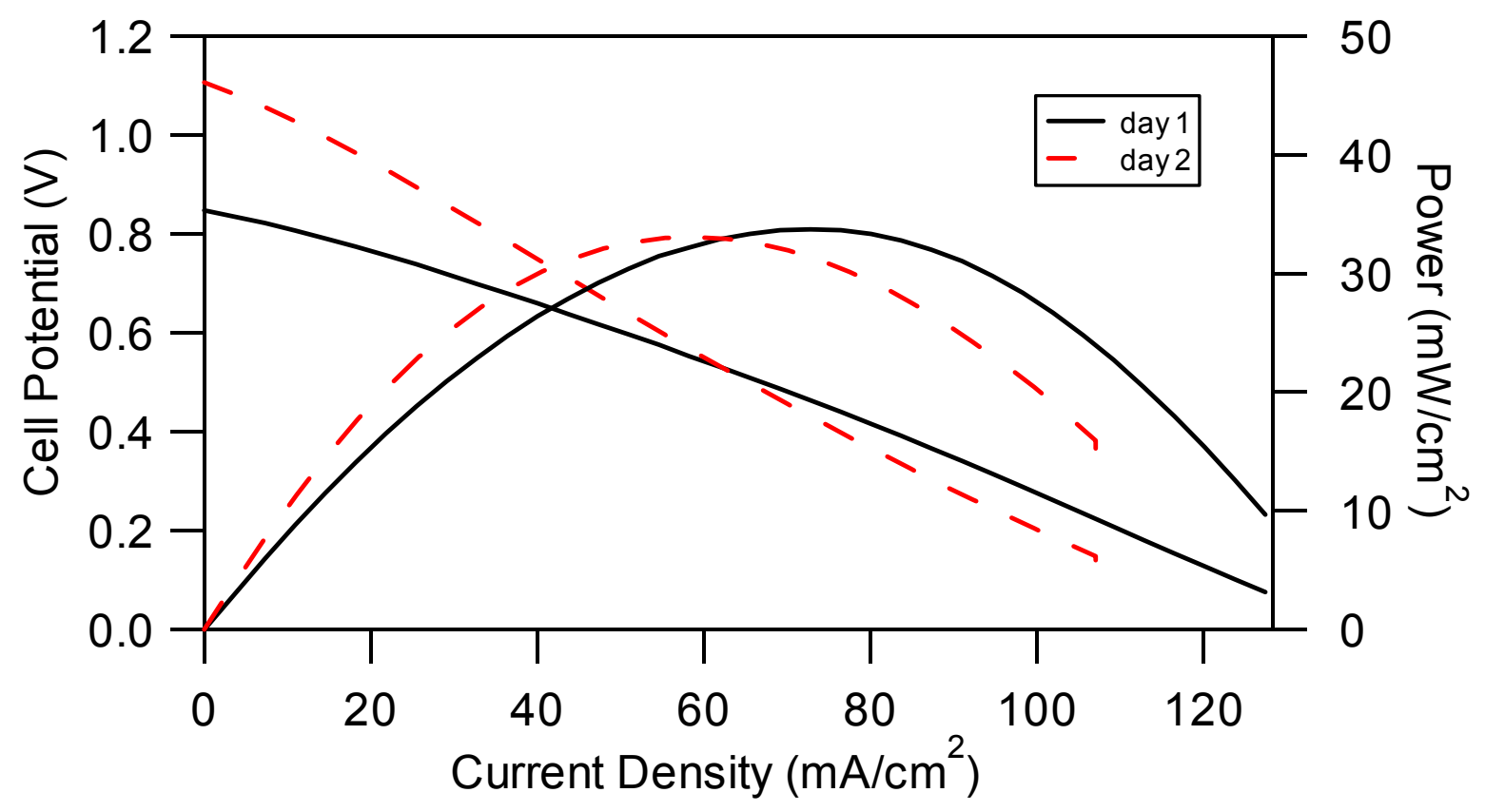


Figure 11.

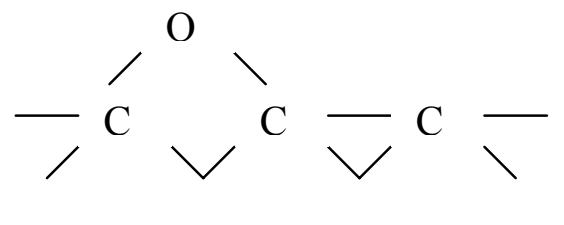

(A)

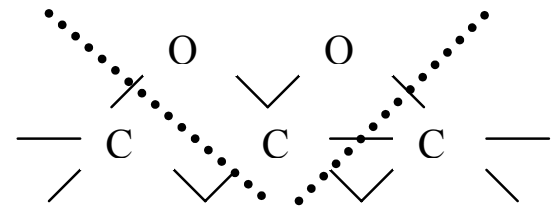

(B) 


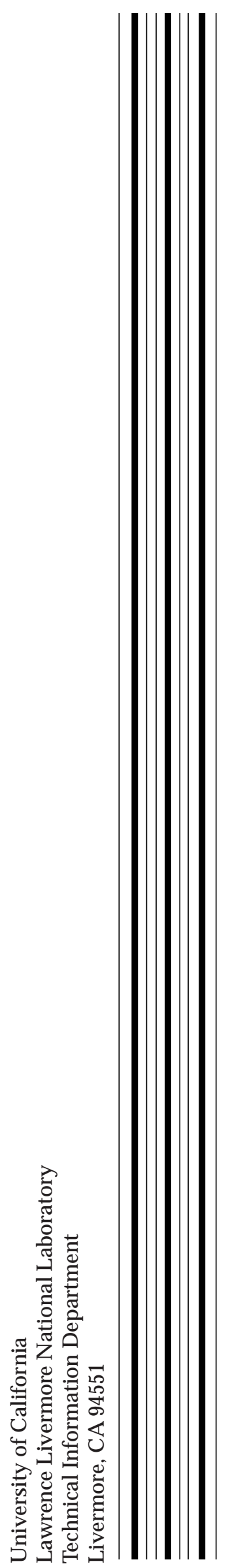

